Michal VanČURA, Martin BlažEK

University of South Bohemia

Tatiana Mintálová, VÁclav ToušEK

Palacký University of Olomouc

\title{
Innovation environment in the Czech Republic
}

\section{INTRODUCTION}

The side effect of the current global economic processes is the ever increasing competitive pressures. Under conditions of the globalizing world economy, the Czech Republic had a good position in particular in the 1990s due to its strategy of the so-called "low-cost economy", above all utilizing low costs as a source of competitive advantage. Under the increasing pressure of big countries with cheap labour, however, the lower price of work cannot be a source of growth and international competitive power in a long-term perspective. The Czech Republic must focus its further economic development on knowledge economy. For this reason, innovation competences of business entities and increasing quality of human resources, research and development of new technologies must become a source of advantages in an increasing manner.

For most business entities, these trends represent a need of fundamental changes in the organization of work, the methods of management, the development of human resources, etc. As a result, the external environment, in which business entities perform their business activity, is changing considerably, and innovative business entities thus become holders of comparative advantages in regional development.

The purpose of the paper is to evaluate the current position of the Czech Republic based on the international comparison of innovation performance, to address strong as well as weak points of the innovation system in the Czech Republic and to describe the regional variability of the innovation potential on the regional level of the Czech Republic.

This article was written with the contribution of the Grant Agency of the Czech Republic and is one of the outputs of the grant assignment no 403/09/0885.

\section{InNOVATION POLICY IN THE CZECh RepUBLIC}

The innovation environment in the Czech Republic started to be developed together with the development of market economy after 1989. As early as in 1993, the Association of Innovative Entrepreneurship of the Czech Republic was established, the goal of which has 
been to create prerequisites for development of innovative business activity, i.e. research, development and innovations, transfer of technologies, new materials and technologies, building up scientific and technical centres and the activity of innovative business entities, which means creating innovative infrastructure and conditions for efficient innovation market (AIP CR, 2002).

In October 1999, a document called "Common evaluation of priorities of economic policy of the Czech Republic for the period until 2005" was completed by the government of the CR in cooperation with the European Commission, and at the same time, work on the proposal entitled "State policy of research and development of the CR" was being completed as well. In that period, a strategic goal for the European innovation policy was determined, which was defined at the Lisbon conference of the Council of Europe in March 2000. The strategy was acknowledged and its importance highlighted even at the follow-up meetings of the Council of Europe, in particular, at the one held in Barcelona in 2002 and in Brussels in March 2003. In the Czech Republic, factors such as insufficient legislative environment in the area of innovations, system barriers in the field of administration of incentives and the innovation process financing, made the government of the Czech Republic commence work on the preparation of the "National Innovation Strategy of the CR", as a basic document to formulate the innovation policy of the Czech Republic (Úřad vlády ČR, 2004). The National Innovation Policy was enacted by the decree of the government in March 2004 and in the middle of 2005, the "National Innovation Policy of the Czech Republic for 2005-2010" was considered and enacted as a fundamental document of the systematic and coordinated policy of the state aiming at creating a general pro-innovation environment.

The basic vision of the innovation policy is the achievement "... of the state when business entities and other organizations in the CR actively innovate their products, technologies and services as well as methods of organization and management, provide for permanent growth of labour productivity and competitive power on international markets. All of the above-mentioned while achieving a high level of employment ... (Úřad vlády ČR, 2005a). This vision is implemented through four basic strategic goals:

1. Consolidate research and development as a source of innovations

2. Create efficient partnership of public and private sectors.

3. Provide for human resources for innovations

4. Make the state administration performance relating to research, development and innovations more effective (Úřrad vlády ČR, 2005a).

For each goal, assignments necessary for its achievement are defined as well as instruments, by means of which the individual assignments will be implemented, and for each instrument, there are measures necessary for its implementation, their coordinator, the date of implementation completion, indicators of (the success of) implementation and the method of evaluation.

Another strategic document called the "Strategy of economic growth of the Czech Republic" relies upon significant support of innovation environment as it is obvious from the vision included in the respective document: "The Czech Republic - knowledge-technology centre of Europe with rising living standards and high employment". To achieve this state, five fundamental priority areas should be focused on: Institutional Environment, Sources of Funding, Infrastructure, Human Resources and in particular Research, Development and Innovation (R\&D\&I) (Úřad vlády ČR, 2005b). In the area of R\&D\&I, the fulfilment of the vision should be achieved in particular by the following: 
- strengthen research and development as a source of innovation,

- create a functional public-private partnership in research, development and innovation,

- provide human resources for research, development and innovation,

- streamline the execution of state administration in research, development and innovation. (Úřad vlády ČR, 2005b)

\section{InNOVATION ENVIRONMENT IN THE CZECH REPUBLIC} AND INTERNATIONAL COMPARISON

The international comparison of innovation performance of the individual member states of the European Union has been published by the European Commission since 2000 on an annual basis. The European Innovation Scoreboard (EIS) is used as a basic instrument for the international comparison of innovation power and innovation performance. This instrument provides for a comprehensive evaluation of innovation performance of countries on the basis of the selected indicators relating to inputs and outputs of innovation activities of business entities, and it is used for the purpose of evaluation of the power of the European Innovation System as well.

Within the framework of EIS, innovation performance is evaluated on the basis of 29 indicators that are grouped into three basic groups. In the first group, called the "ENABLERS", indicators that enable implementation of innovation activities are included. These concern qualified human resources and available financial resources. In the second group, called the "FIRM ACTIVITIES", there are indicators by means of which activities of business entities contributing to implementation of innovations are evaluated. These concern corporate investment in innovations, relations between business entities, cooperation with research organizations, entrepreneurship and utilization of industrial property protection. The third group of indicators is formed by the so-called "OUTPUTS", which means indicators that evaluate both occurrence and effectiveness of innovative business entities and economic impacts of such innovations (Pro Inno Europe, 2009).

In 2008, the Czech Republic was evaluated in EIS as follows:

The Czech Republic is among the group of moderate innovators with innovation performance below the EU27 average but the rate of improvement is above that of the EU27. Relative strengths, compared to the country's average performance, are in firm investments, innovators and economic effects. Relative weaknesses are in throughputs, finance and support and human resources (Pro Inno Europe, 2009).

Over the past 5 years, throughputs, human resources and finance and support have been the main drivers of the improvement in innovation performance, in particular as a result from strong growth in Community designs $(26.0 \%)$, technology balance of payments flows $(13,1 \%)$, S\&E and SSH graduates (14.1\%), private credit (11.8\%) and broadband access by firms $(40,1 \%)$. Performance in innovators has worsened, due to a decrease in SMEs introducing product or process innovations (-2.6\%) (Pro Inno Europe, 2009).

For the purpose of comparison of innovation performance of individual countries, a summary indicator, the so-called Summary Innovation Index (SII) is used. This concerns the unweighted average of standardized values of all the 29 indicators. Based on this index, the Czech Republic ranks (together with other two post-communist countries - Estonia and 
Slovenia) among countries belonging to the group called "moderate innovators" with innovation performance below the EU average (Fig. 2).

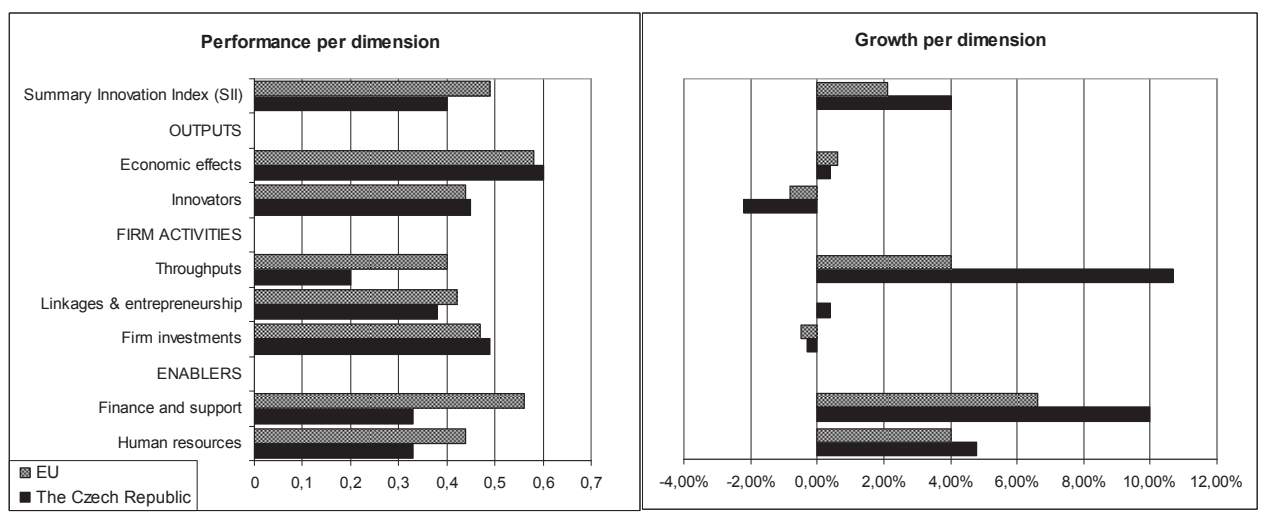

Fig. 1. Basic indicators of innovation performance in the Czech Republic (2008)

Source: European Innovation Scoreboard 2008, Pro Inno Europe, 2009

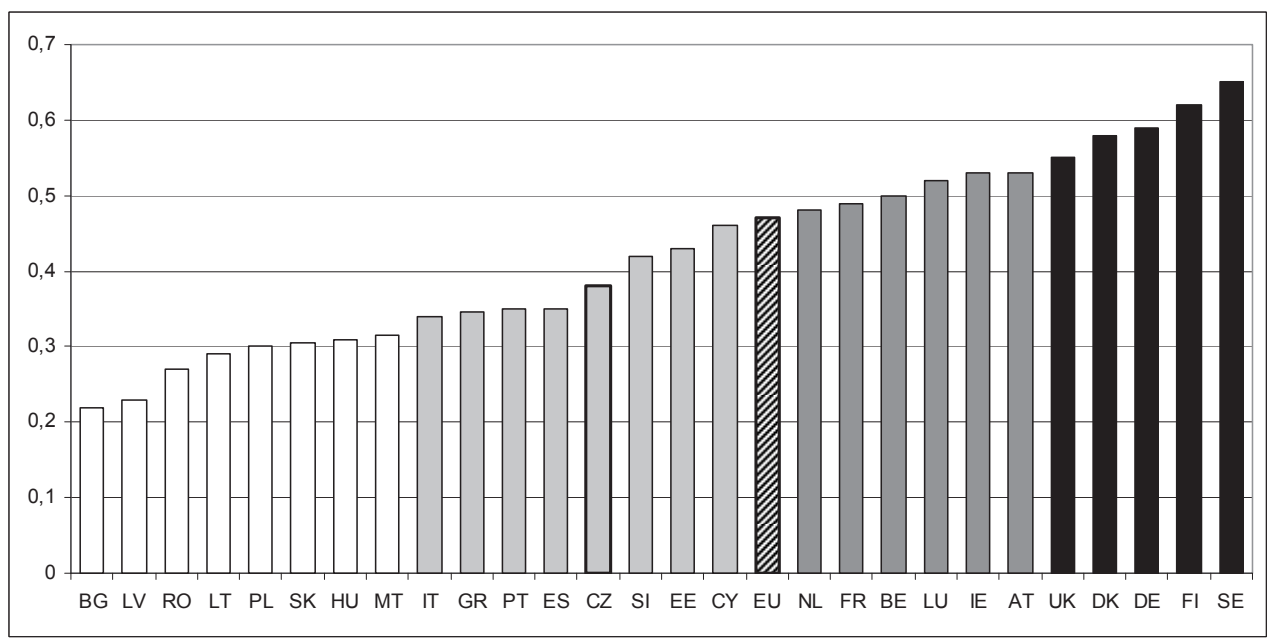

Fig. 2. Summary Innovation Performance EU Member States

Source: European Innovation Scoreboard 2008

Another indicator that is often used for international comparison in the area of innovation potential is the total expenditures on research, development and innovations (R\&D\&I). Based on data published by OECD, even here the Czech Republic ranks among countries with the below-average value, compared to the EU average. However, together with Slovenia, the Czech Republic comes closest of the group of the post-communist countries to the EU27 average values (see Fig. 3). While before 2009, expenditures on R\&D\&I in the Czech Republic were growing every year, for the coming years (2010-2012), the government of the CR, in its future prospects, makes provisions for stagnancy of expenditures on R\&D\&I from the state 
budget on the level lower than CZK 25 billion annually, which is likely to have a negative impact on the position of the CR in the comparison with the other EU27 member states.
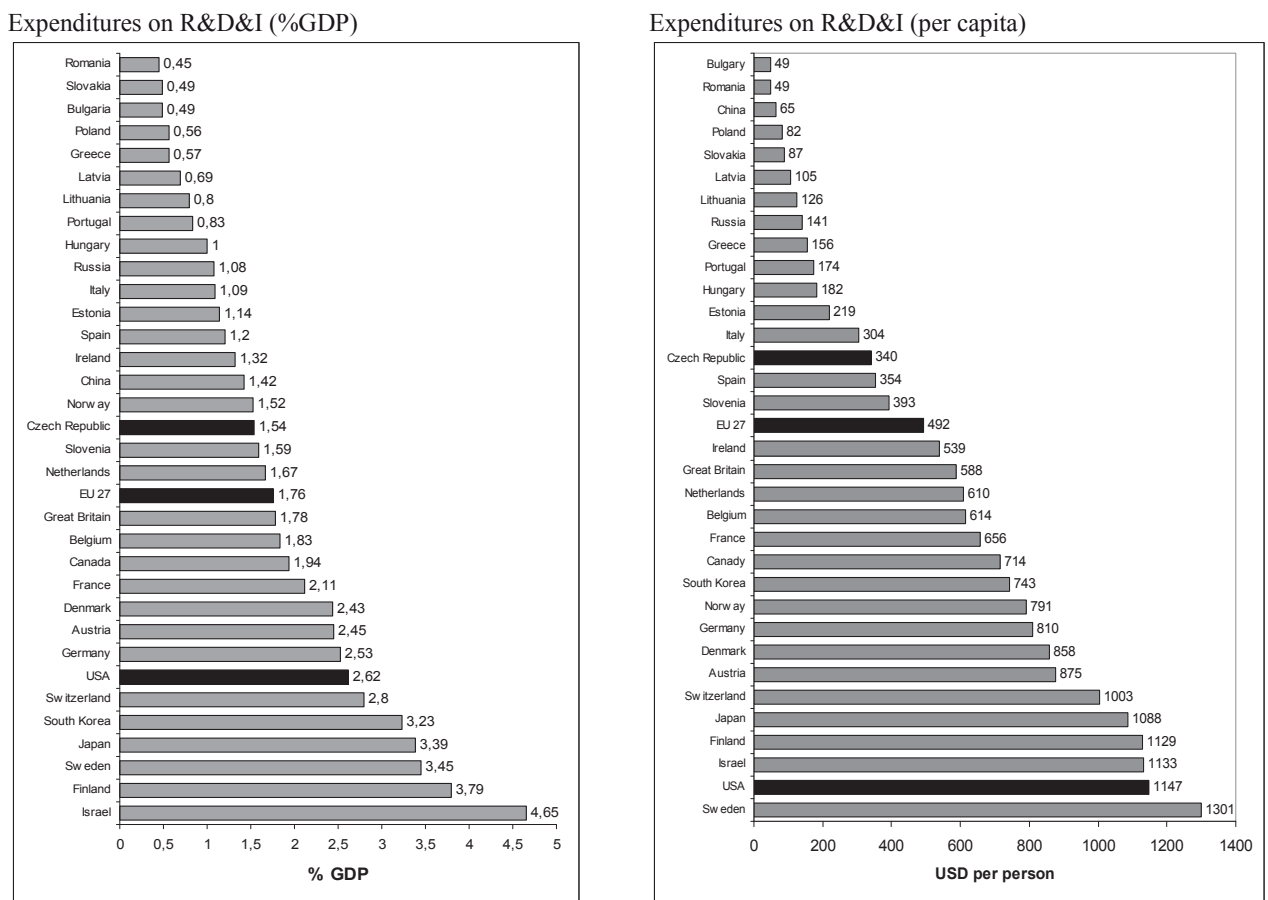

Fig. 3. Expenditures on research, development and innovations (R\&D\&I)

- international comparison (2007)

Source: Main Science and Technology Indicators, 2008/1, OECD, EUROSTAT, 2008

\section{InNOVAtion POTENTIAL OF THE REgIONS OF THE CZECH REPUBLIC}

Innovation potential of the individual regions of the Czech Republic is influenced by a number of factors that can be divided into several groups. For the purpose of evaluation of innovation potential of the regions, Pokorný, O. et al. (2009) work with a great number of variables (39 in total) which they group into partial factor groups, and finally they define in total five large groups of indicators:

- Innovations drivers (Number of Factors 7)

- Students (3), Labour Attraction (2), Agglomeration Advantages (2),

- Knowledges creation (8)

- Concentracion of R\&D (6), Potential of Technology Centres (2),

- Innovation Activities and Business (9)

- Capital Costs(3), Business Estates(2), Project Activity (3), Institutions for Innovations (1)

- Application (8) 
- Macro-economic Indicators (2), High-tech Branches (4), Medium High-tech Branches (2)

- Intellectual Property (5)

- Outputs (4), Costs (1)

Based on the calculation of the weighted averages of the individual variable factors, the innovation potential of the regions of the CR has been evaluated. Among the highly aboveaverage regions, only Prague was included, and among the above-average ones there were South-Moravian Region and Královéhradecký Region, and on the other hand, among the highly below-average regions, there were Karlovarský Region and Vysočina Region (Fig. 4). However, if we compare these results with data concerning development of expenditures on R\&D\&I (Fig. 5), it is obvious that in particular in the case of Vysočina Region and also in the case of Zlínský Region, there is a considerable effort aiming at a marked support of the R\&D\&I sector, which is usually a driving force of the innovation environment. For this reason, it is possible to expect that these regions may achieve better results in the overall evaluation performed in the coming years.

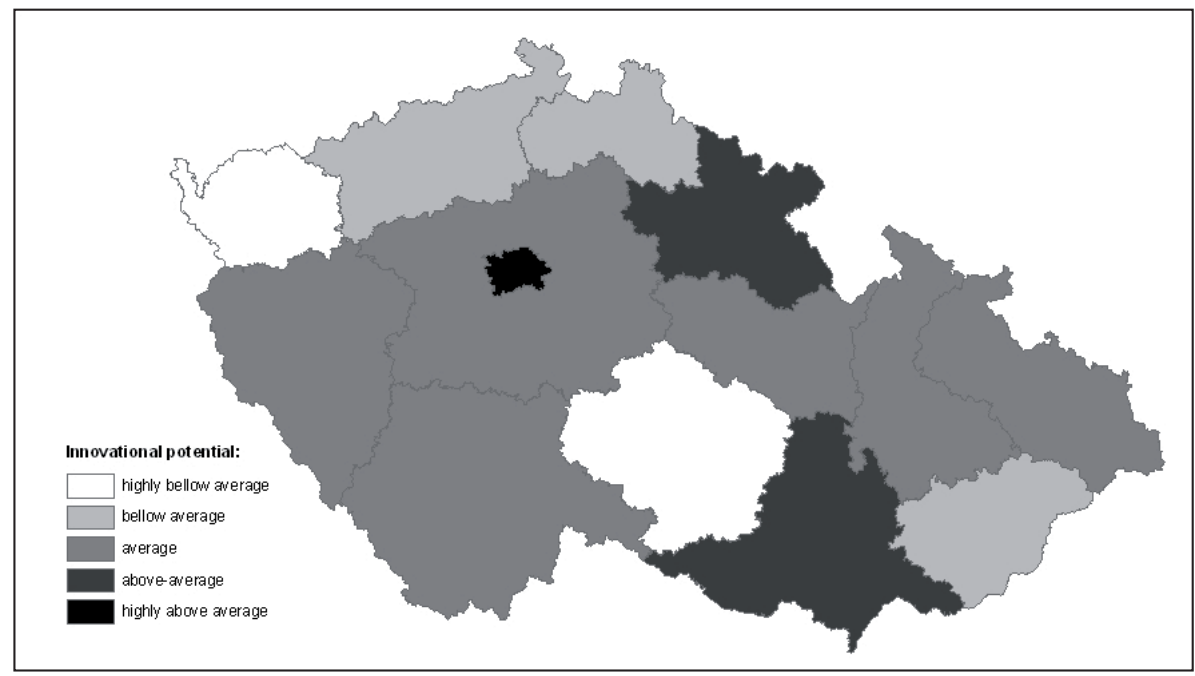

Fig. 4. Innovation potential in the regions of the Czech Republic

Source: Analysis of the innovation potential of the regions of the Czech Republic, Technological Centre of the Academy of Sciences of the Czech Republic, 2008

The multi-criteria approach to the innovation potential evaluation is very competent both on the national and on the regional level (Frantál, B., Klapka, P., 2007). Some partial factors are used very often for the interpretation of innovation environment or potential. Evaluation of innovation environment on the basis of a single indicator, however, can be largely misleading. As an example, it is possible to provide commonly used indicators of the level of employment in high-tech industries. Fig. 6 indicates the ratio of people employed in high-tech fields of the secondary industry in the regions of the CR. The region with the lowest ratio of people employed in this manner is Liberecký Region (similarly, the region has one of the lowest ratio of innovative business entities), which is known for its textile industry, 
glass-making and engineering industry. From Fig 7, which presents the information on the numbers of patents, it is obvious that Liberecký region that comes second after Prague has the highest number of patents in terms of the number of the population. This is mostly due to the extensive tradition of the textile industry (the industrial field that is frequently quoted as an example of a field having low innovation potential) that is closely related to the universities and the scientific institutes in this region (Tonev, Toušek, 2002).

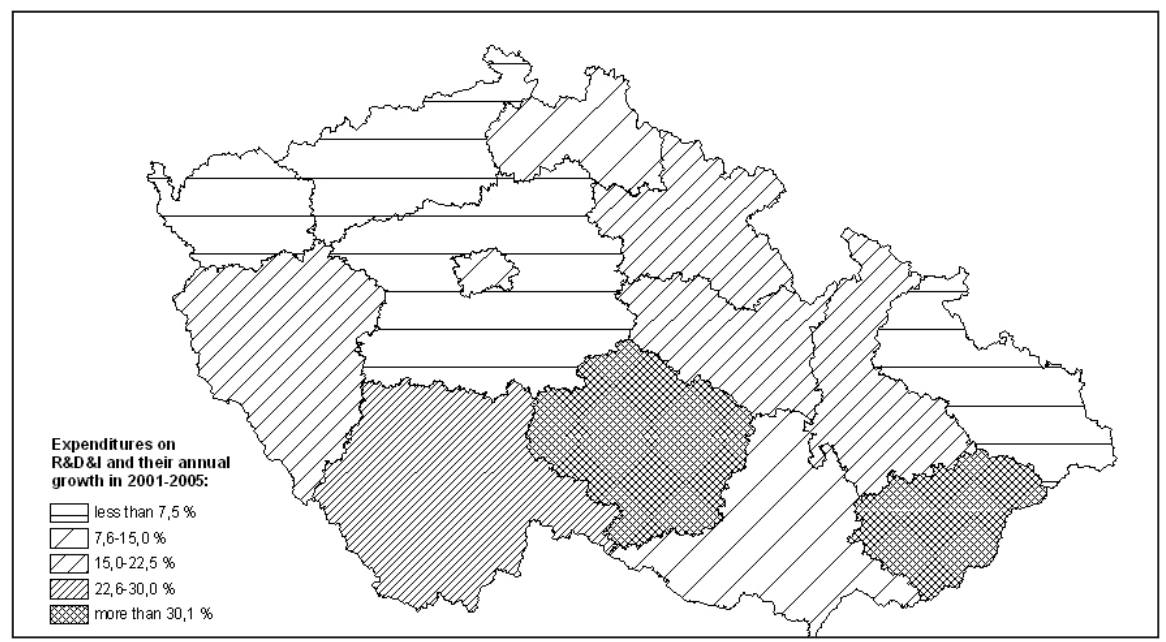

Fig. 5. Expenditures on R\&D\&I and their annual growth in 2001-2005

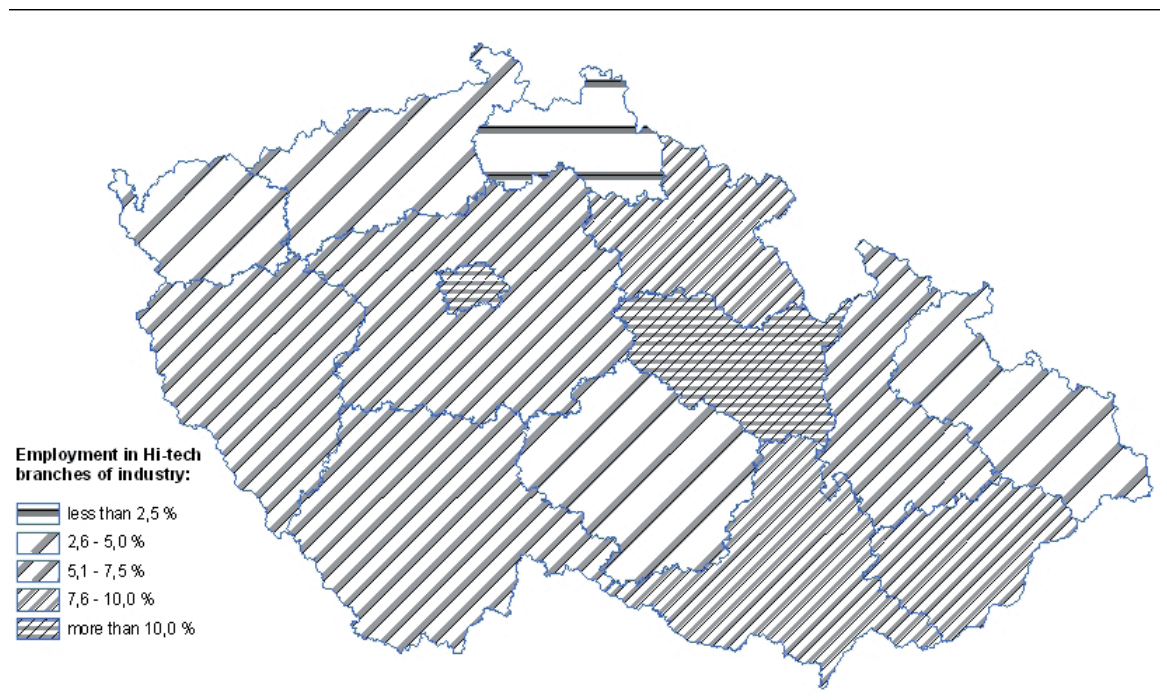

Fig. 6. Employment in high-tech branches of the industry (2005) 


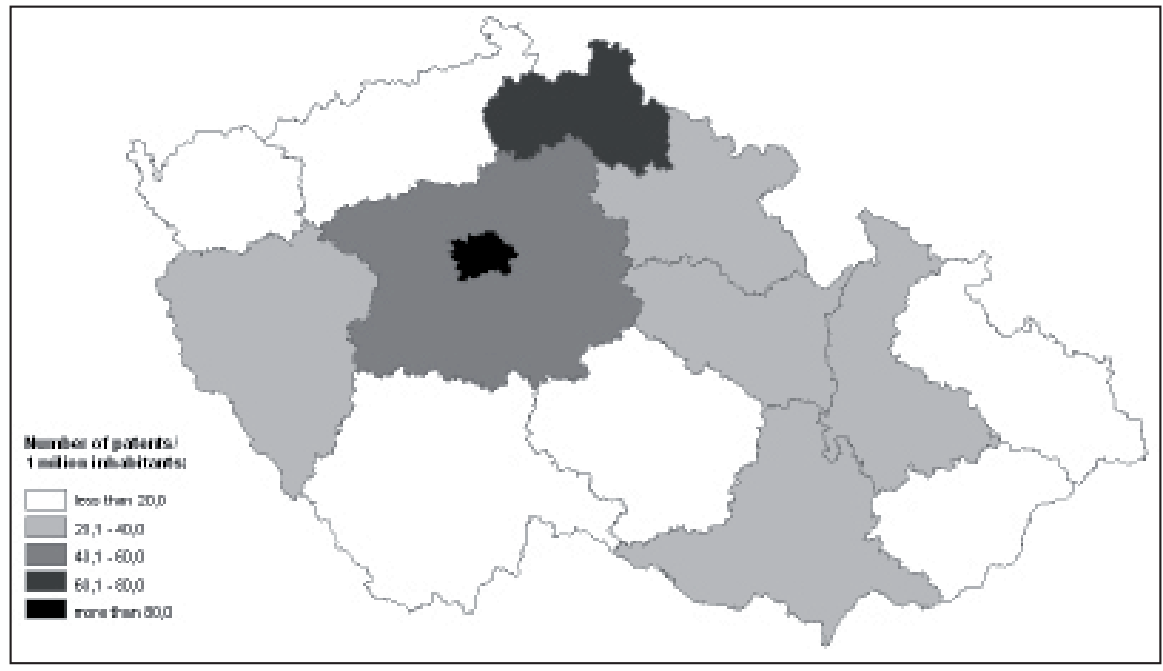

Fig. 7. Number of patents/1 million inhabitants (2005)

Source: Czech Statistical Office, 2007

\section{CONCLUSION}

Within the framework of the international comparison (EU27), the Czech Republic is a country with below-average innovation performance. In the past years, the trend of approaching the EU27 average value was obvious, however, due to the economic crisis and the stagnancy of the state expenditures on R\&D\&I we can expect diminution of this convergence. In spite of this fact, the Czech Republic, together with Slovenia and Estonia, is a country with the best score in the group of post-communist countries. From the regional point of view, there are relatively significant differences in the Czech Republic. Upon application of the multi-criteria evaluation, Jihomoravský Region and Královehradecký Region in addition to Prague are among regions with the highest innovation potential, whereas, the position of Karlovarský Region as well as the position of Vysočina Region is very weak.

\section{References}

AIP ČR, 2002, Stanovy Asociace inovačního podnikáni České republiky, http://www.aipcr.cz/stanovy.asp. Frantál, B., Klapka, P., Kunc, J., 2007, Vybrané aspekty inovačního prostředí v regionech $\check{C} R$. Národohospodářský obzor 7:3, s. 35-45.

OECD, 2008, Main Science and Technology Indicators, 2008/1. OECD, Directorate for Science, Technology and Industry, Paris Cedex.

Pokorný, O., 2009, Analýza inovacního potenciálu regionu CR: výsledky projektu. ERGO - Analýzy a trendy výzkumu, technologií a inovací, Technologické centrum Akademie ved ČR, no. 3, roč. 4, Praha.

Por Inno Europe, 2009, European Innovation Scoreboard 2008. http://www.proinno-europe.eu/ EIS2008/website/docs/EIS_2008_Final_report.pdf.

Tonev, P., Toušek, V., 2002, Typologie okresů České republiky (podle struktury zaměstnaných s důrazem na odvětví zpracovatelského průmyslu), [The Typology of the Czech Republic Districts 
(according to the Structure of Employed with the Emphasis on the Branch of the Manufacturing Industry)]. In: M. Balej (ed.): XX. jubilejní sjezd ČSGS. - Sborník tematického okruhu Regionální rozvoj / regionalizace. - Ústí nad Labem: Univerzita J. E. Purkyně, 2002. - s. 67-78.

Úřad vlády ČR, 2004, Národní inovační strategie České republiky. http://download.mpo.cz/ get/27431/28899/315171/priloha001.doc. Praha.

Úřad vlády ČR, 2005a, Národní inovačni politika České republiky na léta 2005-2010. http://download. mpo.cz/get/26521/28902/315192/priloha001.doc. Praha.

Úřad vlády ČR, 2005b, Strategie hospodářského rưstu České republiky. http://www.vyzkum.cz/storage/att/2E19C964AA2946D68D17482DC5DDFA0D/SHR\%20Expert\%20Final.pdf . Praha.

\section{Innovation environment in the Czech Republic}

The by-product of the current global economic processes is increasing competitive pressure. In conditions of world economy globalization, the Czech Republic was particularly successful in the 1990s, mainly due to the strategy of "low cost economy". Low costs were the primary source of competitive advantage. Increasing pressure of large countries with cheap labour force does not allow the Czech Republic make its labour costs lower and use this as a source of economic growth and international competitiveness. Therefore the Czech Republic was forced to direct its further economic development towards the knowledgebased economy. Due to this new priority, in the economic policy the innovative abilities of the companies, increasing quality of human resources, as well as research and development of the new technologies became the most important tasks. For the most of companies these trends were tantamount with the necessity of basic changes in production process organization, management, human resources development, etc. Both inner and outer entrepreneurial environments were thus considerably changed and innovative companies become the carriers of comparative advantages in the regional development.

The objective of the article is to assess the current position of the Czech Republic in international perspective as far as the innovative efficiency is concerned. The authors also will try to point the strong and weak sides of the innovation system in the Czech Republic. The second part of the paper analyses the innovative potential of particular Czech regions.

Mgr Michal Vančura Ph.D.

University of South Bohemia, Czech Republic

Department of Geography

Pedagogical Faculty

e-mail: vancura@pf.jcu.cz.

RNDr. Tatiana Mintálová

Palacky University in Olomouc, Czech Republic

Department of Geography

Faculty of Science

e-mail: tatiana.mintalova@upol.cz.

Mgr Martin Blažek

University of South Bohemia in České Budějovice, Czech Republic

Department of Geography

Faculty of Education

e-mail: mblazek@pf.jcu.cz

doc. RNDr. Václav TOUŠEK

Palacky University in Olomouc, Czech Republic

Department of Geography

Faculty of Science

e-mail: vaclav.tousek@upol.cz 